\title{
Language and Women
}

\author{
Orhan Bozdemir \\ Correspondence: Orhan Bozdemir, Ataturk University Faculty of Education, Department of German Language Teaching \\ 25240, Erzurum, Turkey
}

Received: December 24, 2015 Accepted: February 14, 2016 Online Published: March 1, 2016

doi:10.11114/jets.v4i5.1265

URL: http://dx.doi.org/10.11114/jets.v4i5.1265

\begin{abstract}
The course of life of women and men has been continuing differently in almost all societies and all fields for ages. The different functions, positions and perspectives of women and men have developed in the societies in which life style bases on male domination, and this situation paves the way for negative results for women. Considering the fact that it is not easy to change the woman perception in the developed and developing societies, we have put some emphasis on the improvements in which men and women will be equal in the field of language at least with small changes in this study. We limited our study with German language and the way of addressing in German. In the first section of the study, we have addressed the issues of language and culture, the relationship between thinking and identity and the humiliation for women in language. After that, we try to reflect the emphasis suggestions as a table which can provide equality in the way of addressing in the second section.
\end{abstract}

Keywords: identity, language and culture

\section{Introduction}

The language may give information on social structures and processes, as it evolves depending on the social development. The usage of the linguistic structures forms a particular awareness-raising in the users, it reflects the apparent reality and it may also strengthen or soften enrolments and prejudices. Even an identity formation takes place over the usage of the language (Doleschal, 1998).

The aim of the current study is to make women and men - the main components of the social life-, their different roles and functions in the society, as well as their different living conditions and consequently arising problems on the linguistic level visible. In the first part of the study, it is attempted to illuminate the connections and interactions among language, culture, identity, gender, power and thinking. The interrelation between language and gender and possible causes of the linguistic behavior (e.g. why women are ignored, denied and debased) are highlighted.

In the second part, guidelines and advice for a gender-neutral language within the range of the forms of address are discussed.

First, one has to think, what the language facilitates for us, what kind of influences the words have on our relations.

Which kind of language may hurt the reputation of other people?

Whether should be there limitations on what we say regarding our thoughts and convictions?

Language is the most important communication tool among humans. With the language; thoughts, emotions and opinions are conveyed and exchanged. Nominations and designations, that are expressed with the language, are tools of organizing our messages and thus of establishing an overview. It enables us to understand others, while we produce and perceive phonetic gestures like expressions and articulations with the language and in doing so we associate the meaning with them. Hence, the language is the most important prerequisite for humans regarding their ability to exist as a member of the society, to communicate and to interact. Without a common language, a mutual communication is impossible. Communication is the most meaningful tool in the society for positioning and enforcement of the individual and social interests. Language shapes our ideas to a phonetic form and thereby it becomes an important, sometimes a useful, but sometimes also a dangerous instrument. A language exists only with its speakers and it is a reflection of their society. According to the scientific theory "linguistic determinism", which was attributed to the language by many scientists (Brunzel, 2002), language and philosophy of life are linked and the cognition of the reality depends on the semantic structure of the language. 


\section{Language and Identity}

As a social entity, every human possesses two kinds of identities. On the one hand there is the "individual" identity, the properties that make the individual unique and differentiate it from other individuals; on the other hand there is the "group-based identity", which called also the "social", "ethnic", "collective" or "we-identity" (Fix, 2003).

According to Wilhelm Oppenrieder and Maria Thurmair, the group-based identity is:

"... The significant characteristics, that shape together a group, the behavior arising from it and the attitudes cherished in the group and that at the same time demarcate it from other groups. In turn, the identities of the groups manifest themselves in behaviors of the group members, whose individual identities are established within the framework of the group. It is expected from them that they behave loyally as members of the group and additionally they back primarily the identity-raising moves of the group." (Oppenrieder \& Thurmair, 2003).

Hence, one's identity is shaped by different factors: One's characteristics, behaviors, preferences, feelings and attitudes. They constitute one's individuality and serve to distinguish the individual from others. On the other hand, one's identity is defined at the same time by the different identities of the society, to which the individual belongs. Therefore, the personal and group-based identities belong together.

Every language has its own style to express the reality. Thus, the language directs and defines the thought. The language shapes the identity. There are concepts that obtain identity through the usage of a language. There are also general ideas like love or conscience that exist without any reference to a language. The language has a great importance for an individual:

"The need to feel oneself represented on a linguistic level, the need for an identity through language and language-identity are genuinely humane and arise in the cohabitation with others." (Greule et al., 2003).

The native language is one's first language and therefore, it is very important for the development of one's personality and it is an important component of the identity. The first language conveys the weltanschauung, socialization and behavior patterns of the society and encodes the further life of the individual. Hearing of a language activates the ideas and prejudices about the country, where the related language is spoken:

"Value judgements of particular languages are transmitted to the users and vice versa the valuations of people and language-groups are projected to such an extent to the languages that they are eventually considered as its immanent properties" (Illius \& Gugenberger, 1999).

"We owe many in our self-feeling, which we perceive as personality, just to the language. And it may arouse the feeling to something like prayer mode in humans: I hear speaking in the language around me and the power of the self flows inside me through the language! - If you have this feeling of the holiness of the invocation, of the self through the language, you can also arouse it in the children within different measures.... If a person actually arouses it, it acts as a fomentation of the will, almost to selflessness, almost to the life with the external world " (Steiner \& Steiner, 1948).

Not only being a tool of communication, the language is also a tool of the construction of the social and cultural human relations and represents the relation between the genders. Therefore, the query about the linkage of language, culture and identity is a central issue concomitantly with the social arrangement and organization.

Classifications, that we need, provide descriptions for experiencing, registering and understanding the variety and quantity with the help of impressions which we structure. Differences and the similarities of the objects become by means of these classifications. In this way, the language enables us to organize several things that we have to know and name, into meaningful categories. Sapir defines the language as a system of freely created symbols:

"Language is a method, eventually unique to humans and not originating from the instincts, for the transmission of thoughts, feelings and wills by means of a system consisting of freely created symbols" (Sapir, 1921).

The language is something wonderful, something fascinating, because it exhibits numerous variations, it is subject to the cultural evolution, it is anthropologically well-founded and thus it contributes to the identity of a group. It serves to the layout of the social relations. This property makes the language a part of the culture and users' continuous formation of the culture. Because if a child hears a language, it learns a linguistic codex, a particular sound combination, a grammatical rule, a syntactic structure, but also the mindset, the way of thinking of the people lived in the past. Besides these, the language serves to the formation of a value system for the individual practice in the social group (religious rituals), for the use of the knowledge that has developed in this society (technology, economy etc.). The history of a language reflects the social history of the relevant people. Root words of a language show which objects were most important for the people at the time of the formation of the language. The thesaurus of a language indicates what people think, the syntax shows how they think. And the child obtains its place in the society with the help of the language it learns: 
"It discloses itself to the others but at the same time, it differentiates itself and in this way it resolves the question about its identity... By the means of the language, one can act instead of only to behave, that is, it can change the reality by acting" (Illius et al., 1999; Pelz, 1996). How far the power of the language extends, shows the ability to wipe out the individuality with the language. Humans are deemed to individuals, hence they are unique in all peculiarities and characteristics. Therefore, language accomplishes consciousness. The word stands between the human consciousness and the meant object. The word takes them apart, as it enables the humans to distinguish the imagination produced by the word from the object, without the word the imagination might not emerge. But the word binds also the object and consciousness. Without the word, the imagination might not become the symbol of that what is meant:

"By means of the language, the whole reality of experience and the thought can make themselves to their own object of knowledge, they may objectify themselves und can be forwarded to others: they become transferable. The language, the self-objectifiable mind, become the body of the mind. The mind is wrapped in the word." (Seebass, 2012).

\section{Language and Culture}

One may define ideas, norms, concepts and values of the members in a society to the culture. It is regarded as self-evident that one takes over the values and norms of the culture, in which one grows up. The culture defines its own value and behavior patterns and these norms are so firm anchored in one's mind that one is led by them for decisions in an unconscious and unquestioned way. For humans their own culture is the measure for valuation. The opinion that their own norms, habits and customs are the only true ones, is anchored in them. Of course, the language plays here the most important role. For Putzer, the language is an indispensable and prominent characteristic of a nation:

"All people that belong to a nation, speak the same language" (Weinrich, 1993).

On the other hand, the language is also embossed by our value ideas, cliché and prejudices.

Because the values and notions of a person are reflected in his language. A person builds his/her weltanschauung on the base of the cultural values which he/she encounters through his/her native language. With time, a person gains the ability to judge how far his current cultural perception conforms his behavior. Therefore, the language cannot be imagined without world-perception, identity and cultural heritage.

As the language is based on the exchange of speaker's and listener's views, it serves to the formation of the social relations. That feature makes the language a part of the culture and carriers' continuous creation of the culture. The language serves to the formation of a value system (religion) for the individual practice in a social group (ritual, traditions), it serves to the management of the social knowledge (economy, technology) (Daum \& Sprache, 1998). All these are acquired in the childhood and a place in the society is achieved through the language which one learns. The person communicates himself to others, but at the same time, he demarcates himself from others and in this way he resolves the question about his identity.

\section{Language and Thinking}

The word stands between the consciousness of the speaker and the meant object. It takes part in the style of being of both. We mean something with every word we speak. The word separates the consciousness and the object. Without the word, the speaker cannot distinguish the generated idea from the object. With the word the idea appears in us. However, the word binds also the object with the consciousness. With the word the idea becomes a symbol of what is meant. The history of a language reflects the social development of the related society. Root words of a language show which objects were most important for the people at the time of the formation of the language. The vocabulary and the syntax of a language show, how and what people think. A society is best characterized by the language. The social content of gender is also formed by different factors:

"A masculine or feminine appearance of a body is the starting point of different labeling as boy or girl by physicians and parents - even if it does run contrary to the genetic or gonadic features (gender of the germ cells)" (Bilden, 1991).

Socialisation starts with one's birth. It is a lifelong, continuous process of contention of the person with his socio-cultural environment:

"The totality of all processes, in their course the individual becomes an active member of the society and culture. (...) Socialization is at the same time a) "socialization" of the person in terms of takeover and internalization (Verinnerlichung) of the socio-cultural values, behavioural expectations and social roles as well as b) personalization of human in terms of "individuation" of his individually determined contention with the offerings and influences of his society" (Endruweit et al., 1989).

In the first phase, the interaction with the mother constitutes the first stage for the development of the identity and for the formation of the basic personality.

In the second phase, the child has contact with the fundamental cultural elements, which are transmitted and filtrated by 
the family. In this phase, the official formation starts too. "Playing, learning, working are three sequential types of activity and environmental relations, in which socialization takes place. They are following each other in the history of the person."

Bilden suggests that the gender-specific socialization develops also in this phase:

"Many girls become more socialized before their mode of socialization becomes "passive". "Self-socialization" plays mostly a greater role in boys, their mode of socialization is more "active" (Bilden, 1991). Girls are considered as weak, ductile and flexible. Independent exploration is not encouraged and they are mostly kept at home.

The third phase is the takeover of the social role which corresponds to the expectations of the society.

With every word, which we speak, we mean something. The word stands between our consciousness and the meant object. It enables us, to distinguish the idea formed by the word from the object. Without the word, the idea in us and in others will not emerge. The word binds also the consciousness and the object. That, what we think becomes through the word the symbol of the development:

"By means of the language, the whole reality of experience and the thought can make themselves to their own object of the insight, can objectify themselves and can be passed on others: they become deliverable. The language, a mind objected in itself, becomes the body of the mind. The mind is wrapped in the word" (Lawitschka, 2008).

With the language we understand everything. Every object becomes the carrier of a being and becomes mentally available.

\section{Discrimination with Language}

With the language one can describe, announce and threaten. Words can even put on something.

"From the gentle irony to the sarcastic mockery, from the indiscreet tactlessness up to bare insult, from condescending humiliation up to discriminating hate speech, the language can act as a force" (Anhut \& Heitmeyer, 2005) .

Words appear externally, so that they fade fast, have no substance and establish nothing permanent. They are not merely symbols which try to intervene with our material world. With words, we can express our feelings in a positive or negative way. With words we cannot let one's body bleed, we cannot inflict wounds to anyone or kill anyone. However, we can hurt someone deeply with our words and put on someone with the language. Language may hurt people in different ways. Linguistic violence and discrimination are directed straight against people. People can speak out ethical or psychological force like slanders, threats or insults, disparagement, mockery, ridicule and marginalization (Menke \& Honneth, 2006). All these forms of force we exert with language. According to Petra Gehring, language can function as a hitting thing. The hurting act of speaking is not a speech act anymore, it approximates to a mute act, to a beat. The language provides us an endless list of concepts, which enables us to express the violent acts in the form of speech: we criticize, judge, suspect, slander, betray, insult, talk tactlessly, threaten, curse, provoke, tease, mock...(Grundmann et al., 2008)

\section{Discrimination of Woman with the Language}

Today, women in Europe and in all highly-developed countries are equal to men thanks to the education opportunities and to the social competence compared to women in the under-developed countries. They obtained many political rights, the right of voting and the right of standing for election. Many women get an academic education and good positions. They took over important leading positions in the society. Hence, in these countries, women and men have the same rights and chances. However, the usage of language shows whether that is true or not in the highly-developed countries. Gender-equal language is still an important issue. We will deal here with a good example: "Forms of address in German" (Foucault et al., 1983).

If the language is an important component of the society and if just a part of the society feel discriminated by the language, here is something not right:

"The women feel discriminated if the language is displayed only in stereotypical roles and thus it disputes them interests and abilities beyond the stereotype and if it makes women submissive and ridiculous by the condescending language" (Meineke \& Frank, 1992; Trömel-Plötz, 2004).

Luise F. Pusch believes that women have the feeling that their identity is not recognizable in the language:

"It is existentially important for all people, to be perceived, to be respected and confirmed in their identity by others.... But women were and are often in a schizophrenic situation so that even their identity as "a human being" was not confirmed" (Pusch, 1988).

Many Linguists, scientists and authors have dealt with the gender-specific scope of the language, as communication and a gender-equal communication is an important component of the socio-linguistic research. Shannon Weafer emphasizes 
the importance of the transmission of information:

"A transmitter wants to communicate something. He encodes his issues in recognizable symbols and transmits a message to the recipients over a medium. The receiver recognizes these symbols, decodes them and process the message" (Samel, 1995).

For communication, particularly the expression of feelings, the description of facts is important. In meetings of men and women, independent from being a professional, friendly or intimate meeting, communicative problems emerge. The communication is mostly disrupted. Communication problems occur between the transmitter and the recipient:

"The dissatisfaction of women with the German language is not primarily a problem of the language systems but a problem of the language-usage" (Hufeisen, 1993). The German language has many possibilities to make women linguistically visible. Besides this, the language changes with time. Some words get older and they are used to a lesser extent or not at all. For example, the old form of address "Herr" (mister) became "Mann" (man). With the new form of address of „Männer" (men) are not anymore called, talked or written as "Herren” (mister) and become equal men. So, equality and gender-equality between women and men are expressed (Froitzheim, 1980). The forms of address "Herr" (mister) and "Frau" (mistress) are equivalent and do not convey any linguistic symmetry. The equivalent of the form of address "Frau" is the form of address "Mann". The form of address "Herr" originates from the times of feudalism and slavery. It designates a man of high social status and noble origin that rule his underlings. In 1977, the concept "Herr" nominated the head of the family. The word "Herr" claims the reign, also the reign over women. Unlike from the designation "Herr", the designation "Frau" is not only a form of address but it nominates also the biologic gender. Independent from the origin of the word "Frau", "Frau" and "Herr" are not equivalent and are not considered as equivalent forms of address by many users (Aebischer, 1980).

A language with gender-awareness should let one to speak out women and men directly and personally and should make both of them equally visible.

The German Language has basically three possibilities to formulate gender-equality:

Restatements (rewordings)

Pair-forms

Gender-neutral and gender-abstract formulations

In this last section we will try to show on tables how the new formulations can be utilized (Tablo 1-6). 
Table 1. Forms of Address

\begin{tabular}{|c|c|c|}
\hline Old & New & Comment \\
\hline Dear Sirs! & Dear Madam / Sirs & $\begin{array}{l}\text { "Dear Sirs" acts impersonal and refers only to one } \\
\text { gender. }\end{array}$ \\
\hline Miss. Krause & Mrs. Krause & $\begin{array}{l}\text { Until the decree of the Federal Ministry of Interior in } \\
\text { 1972, "Mädchen" (Miss) was the official form of } \\
\text { address for unmarried women irrespective of the age. } \\
\text { Today it is common to speak to female persons with } \\
\text { "Mrs." }\end{array}$ \\
\hline Mr. Wolfgang Schröder and Mrs. & $\begin{array}{l}\text { Mr. and Mrs. Schröder; Mr. } \\
\text { Wolfgang Schröder and Mrs. } \\
\text { Angelika Schröder }\end{array}$ & Every person is spoken individually and separately. \\
\hline Family Peter Wüst & $\begin{array}{l}\text { Family Wüst; Family Beate and } \\
\text { Peter Wüst; Mr. Peter Wüst and } \\
\text { Mrs. Beate Wüst }\end{array}$ & $\begin{array}{l}\text { Either the family name is used as a general form of } \\
\text { address or the member of the family are spoken } \\
\text { individually. }\end{array}$ \\
\hline Mälzer, Surgeon & Mälzer, Surgeon & The forms of address are used symmetrically. If a \\
\hline Mrs. Graf, nurse & Graf, nurse & $\begin{array}{l}\text { person is recognized only with the surname or is } \\
\text { spoken with "Mrs./Mr.", this scheme is used also }\end{array}$ \\
\hline Mrs. Blum, Süddeutsche Zeitung & Mrs. Blum, Süddeutsche Zeitung & with other persons. \\
\hline Raab, Berliner Morgenpost & Mr. Raab, Berliner Morgenpost & \\
\hline US-president Obama & $\begin{array}{lll}\text { US-president } & \text { Obama } & \text { und }\end{array}$ & Neither women nor men are disrespected or \\
\hline Und Mrs. Merkel & $\begin{array}{l}\text { Federal Chancellor Merkel; Mrs. } \\
\text { Merkel and Mr. Obama }\end{array}$ & $\begin{array}{l}\text { sublimed. If the publicity of the person cannot be } \\
\text { presumed, the use of the forename is recommended. }\end{array}$ \\
\hline Krause and Maria Kunze & $\begin{array}{l}\text { Krause and Kunze; } \\
\text { Anina Krause and Maria Kunze }\end{array}$ & Name and Surname are used in the same proportion. \\
\hline $\begin{array}{l}\text { Riemann D. } \\
\text { Jäger, Y. } \\
\text { Uhl, G. }\end{array}$ & $\begin{array}{l}\text { Riemann, Dennis } \\
\text { Jäger, Yvonne } \\
\text { Uhl, Günter }\end{array}$ & $\begin{array}{l}\text { In scientific, literal and competent papers the } \\
\text { forenames should be written, in order to avoid } \\
\text { misunderstandings regarding the gender. }\end{array}$ \\
\hline Dear Mrs. Doctor Peters & $\begin{array}{l}\text { Dear Mrs. Dr. Peters; Dear Mrs. } \\
\text { Doctor (Ger: Doktorin: female } \\
\text { doctor) }\end{array}$ & $\begin{array}{l}\text { Titles like "lecturer", "doctor", "professor" should be } \\
\text { written in female forms. "Mrs. Doctor", "Mrs. } \\
\text { Professor" are also acceptable, although the way of } \\
\text { writing "Mrs. Professor (Ger: Professorin: female } \\
\text { professor) is recommended. }\end{array}$ \\
\hline Dear Mrs. Senator & $\begin{array}{l}\text { Dear Senator (Ger: Senatorin: } \\
\text { female senator) }\end{array}$ & \\
\hline Dear Mrs. Professor Schneider & $\begin{array}{l}\text { Dear Mrs. Prof. Schneider; } \\
\text { Dear Mrs. Professor (Ger: } \\
\text { Professorin: female professor) } \\
\text { Schneider }\end{array}$ & \\
\hline $\begin{array}{l}\text { We ask Mr. David Sohl and wife to come } \\
\text { in the room } 102 \text {. }\end{array}$ & $\begin{array}{l}\text { We ask Mrs. and Mr. Sohl to } \\
\text { come in the room 102; } \\
\text { We ask Mrs. Gloria Sohl and Mr. } \\
\text { David Sohl to come in the room } \\
102 \text {. }\end{array}$ & $\begin{array}{l}\text { Symmetrical use of the names, if they are known, is } \\
\text { recommended. }\end{array}$ \\
\hline
\end{tabular}

Table 2. Designations of the Profession and Work

\begin{tabular}{lll}
\hline Old- & New & Comment \\
\hline All students & All female and male students & $\begin{array}{l}\text { If both genders is meant, then they should be spoken } \\
\text { individually. This is also called splitting, that is the } \\
\text { separation of the persons, which are spoken to. }\end{array}$ \\
\hline Every worker & $\begin{array}{l}\text { Every female worker (Ger: Also the common sequence masculine - feminine can be } \\
\text { Arbeiterin) and every male worker often reversed. } \\
\text { (Arbeiter); } \\
\text { Every work force, all working } \\
\text { persons, the working staff }\end{array}$ \\
\hline $\begin{array}{l}\text { A Lawyer } \\
\begin{array}{l}\text { No Lawyer (Ger: Anwalt) shall break his } \\
\text { silence. }\end{array}\end{array}$ & $\begin{array}{l}\text { A female lawyer (Ger: Anwältin), a } \\
\text { male lawyer (Anwalt) } \\
\text { Lawyers shall not break their silence. }\end{array}$ \\
\hline
\end{tabular}


Table 3. General form of address

\begin{tabular}{|c|c|c|}
\hline Old & New & Comment \\
\hline The Voter & $\begin{array}{l}\text { The female voter (Ger: } \\
\text { Wählerin), the male voter (Ger: } \\
\text { Wähler) }\end{array}$ & $\begin{array}{l}\text { If men and women are spoken equally, the splitting } \\
\text { may be done in different ways. }\end{array}$ \\
\hline The Resident & $\begin{array}{l}\text { The female resident (Ger: } \\
\text { Bewohnerin), the male resident } \\
\text { (Ger: Bewohner) } \\
\text { The female seller (Ger: Käuferin), } \\
\text { the male seller (Ger: Käufer) }\end{array}$ & \\
\hline The Seller & $\begin{array}{l}\text { Female promoter (Ger: } \\
\text { Bewerberin) and male promoter } \\
\text { (Ger: Bewerber), please report! }\end{array}$ & \\
\hline \multicolumn{3}{|l|}{ Promoter, please report! } \\
\hline $\begin{array}{l}\text { every worker } \\
\text { every employer }\end{array}$ & $\begin{array}{l}\text { every working person, all workers } \\
\text { who employs someone, the } \\
\text { responsible person for work } \\
\text { distribution }\end{array}$ & $\begin{array}{l}\text { If a splitting is not wanted, rewordings with the } \\
\text { neutral plural should be used. }\end{array}$ \\
\hline every employee & all who are active in a workplace & \\
\hline We have a room for non-smokers. & $\begin{array}{l}\text { is allowed only in this room. } \\
\text { Private parking, }\end{array}$ & \\
\hline Staff parking lot & $\begin{array}{l}\text { Parking area of the company XX, } \\
\text { Parking area only for the staff of } \\
\text { the company XX }\end{array}$ & \\
\hline $\begin{array}{l}\text { A patient, a police officer, a traveller } \\
\text { The young } \\
\text { The responsible }\end{array}$ & $\begin{array}{l}\text { Patients, police officers, travellers } \\
\text { The young (plural) } \\
\text { The responsibles }\end{array}$ & If possible, the neutral plural is used. \\
\hline $\begin{array}{l}\text { The roots of our fathers lay in... } \\
\text { Not anymore being the lord of oneself }\end{array}$ & $\begin{array}{l}\text { The roots of our ancestors lay } \\
\text { in... } \\
\text { To be confused. }\end{array}$ & $\begin{array}{l}\text { Patriarchal expressions can be changed with neutral } \\
\text { expressions. }\end{array}$ \\
\hline
\end{tabular}

Table 4. Use of Pronouns

\begin{tabular}{lll}
\hline Old & New & Comment \\
\hline Someone has taken my pen. & $\begin{array}{l}\text { A person has taken my pen. He or } \\
\text { she has taken my pen. }\end{array}$ & Usage of relative pronoun "someone" \\
\hline $\begin{array}{l}\text { Nobody should be discriminated because } \\
\text { of his disability. }\end{array}$ & $\begin{array}{l}\text { Nobody should be discriminated } \\
\text { because of his or her disability. } \\
\text { Nobody should be discriminated } \\
\text { because of a disability. }\end{array}$ & Usage of possessive pronouns or a transcription. \\
\hline There was nobody, who has not promoted. & $\begin{array}{l}\text { There was nobody, who (he or } \\
\text { she) has not promoted. }\end{array}$ & Masculine forms are replaced with neutral forms. \\
\hline $\begin{array}{l}\text { Smoking is prohibited, everybody who } \\
\text { works here, knows that. }\end{array}$ & $\begin{array}{l}\text { Smoking is prohibited, all who } \\
\text { work here know that. }\end{array}$ & Usage of the plural "all". \\
\hline $\begin{array}{l}\text { Someone feels overstrained by the daily } \\
\text { tasks. }\end{array}$ & $\begin{array}{l}\text { Many feel overstrained by the } \\
\text { daily tasks. }\end{array}$ & $\begin{array}{l}\text { Usage of the plural "many". Herewith a confusion of } \\
\text { genders is avoided. }\end{array}$ \\
\hline $\begin{array}{l}\text { Who has an idea for the birthday party, he } \\
\text { should get in touch. }\end{array}$ & $\begin{array}{l}\text { Should a person among you has } \\
\text { an idea for the birthday party, he } \\
\text { or she should get in touch. }\end{array}$ & \\
\hline
\end{tabular}

Table 5. Usage of the pronoun "one" (Ger: man)

\begin{tabular}{lll}
\hline Old & New & Comment \\
\hline $\begin{array}{l}\text { A well-groomed appearance is very } \\
\text { important in the job interview. Therefore, }\end{array}$ & $\begin{array}{l}\text { A well-groomed appearance is } \\
\text { very important in the job } \\
\text { should pay attention to his care. }\end{array}$ & $\begin{array}{l}\text { The usage of indefinite pronouns "one" (Ger: man) is } \\
\text { common. Avoidance of its use is not recommended } \\
\text { interview. Therefore, female and but there are alternatives like: I, we, she, You (Ger: } \\
\text { male applicants should get } \\
\text { properly dressed and should pay } \\
\text { attention to his/her care. }\end{array}$ \\
\hline $\begin{array}{l}\text { Television makes the eyes tired. One } \\
\text { realizes it, if one watch television for long } \\
\text { hours. }\end{array}$ & $\begin{array}{l}\text { Television makes the eyes tired. } \\
\text { You realize it, if You watch } \\
\text { television for long hours. }\end{array}$ \\
\hline $\begin{array}{l}\text { One should use headphone during calling } \\
\text { with a handy. }\end{array}$ & $\begin{array}{l}\text { While calling with a handy, } \\
\text { headphone should be used. }\end{array}$ \\
\hline $\begin{array}{l}\text { One can prevent the burning of puddings } \\
\text { with constant stirring. }\end{array}$ & $\begin{array}{l}\text { Burning of puddings can be Rewording with "let" (Ger: lassen). } \\
\text { prevented with constant stirring. } \\
\text { (Ger: Anbrennen des Puddings }\end{array}$ \\
& $\begin{array}{l}\text { läss sich durch ständiges } \\
\text { Umrühren verhindern). }\end{array}$ \\
\hline $\begin{array}{l}\text { How can a woman combine } \\
\text { family and career? }\end{array}$ & $\begin{array}{l}\text { How can woman combine family } \\
\text { and career? }\end{array}$ \\
\hline
\end{tabular}


Table 6. Speakings containing masculine designation

\begin{tabular}{|c|c|c|}
\hline Old & New & Comment \\
\hline $\begin{array}{l}\text { Reader's opinion (Ger: Leser) } \\
\text { Worker's daily life (Ger: Arbeiter) }\end{array}$ & $\begin{array}{l}\text { Female reader's opinion (Ger: } \\
\text { Leserin) } \\
\text { Female worker's daily life (Ger: } \\
\text { Arbeiterin) }\end{array}$ & $\begin{array}{l}\text { If the involved person is a woman, the usage of the } \\
\text { feminine form is recommended. }\end{array}$ \\
\hline $\begin{array}{l}\text { Spectator's letters (Ger: Zuschauer) } \\
\text { Politician's round (Ger:Politiker) }\end{array}$ & $\begin{array}{l}\text { Female spectator's letters (Ger: } \\
\text { Zuschauerin) } \\
\text { Female politician's round (Ger: } \\
\text { Politikerin) }\end{array}$ & \\
\hline $\begin{array}{l}\text { Presidential election } \\
\text { Chancellor's election } \\
\text { Party leader election }\end{array}$ & $\begin{array}{l}\text { Election of... } \\
\text { President } \\
\text { Chancellor } \\
\text { Party leader } \\
\end{array}$ & \\
\hline $\begin{array}{l}\text { The german sports team (Ger: die } \\
\text { Sportsmannschaft) }\end{array}$ & $\begin{array}{l}\text { The german sports team } \\
\text { (Ger: das Team) }\end{array}$ & $\begin{array}{l}\text { If the women can be included in a group, } \\
\text { the masculine form should be avoided. }\end{array}$ \\
\hline $\begin{array}{l}\text { One of the team (Ger: die } \\
\text { Mannschaft) has always the ball. }\end{array}$ & $\begin{array}{l}\text { One of the team (Ger: das } \\
\text { Team) has always the ball. }\end{array}$ & \\
\hline
\end{tabular}

\section{Concluding Remarks}

Also, in the highly-developed countries even today there are areas, where women and men are not equal. In order to materialize the equality in all areas, the usage of the language should be taken into consideration. For a gender-equal usage of the language, there is not a generally accepted formula. The introduced possibilities have advantages and disadvantages. Research on this subject shows that the majority of the women side very strongly with gender-equal language, strengthening the social position of the woman and the equalization on the linguistic level, from which not only a consciousness shift but also a tendency of a further spread of the gender-equal language can be derived.

In order to avoid an insensitive or discriminative usage of the language:

Avoidance of hurting, insulting or discriminating expressions, descriptions, concepts or paraphrases for others, which are known as swearwords.

To make women and men aware of preconceptions in the society and in the language. Linguistic preconceptions are hostile simplifications of the human doings and actions.

The language is a constitutive element both of the changes of the social relationships and of the stabilization of these relationships and it is recognized as an active tool. It has a direct influence on the social conditions, trends and power structures. But it is also vivid. Usage of the language and meanings are constantly changing. A gender-equal language respects both women and men equally and is based on two important principles: Visualization and symmetry.

But it is noteworthy to mention that it is much worse for women e.g. in the Arabic countries, although the Arabic language contains these recommended formulations.

\section{References}

Aebischer, V. (1980). Revue Osnabrücker Beitrage zur Sprachtheorie (Vol. 8-9; Beiheft 3). Langage et société, 12(1), 89-92. http://dx.doi.org/10.3917/ls.109.0075

Anhut, R., \& Heitmeyer, W. (2005). Desintegration, Anerkennungsbilanzen und die Rolle sozialer Vergleichsprozesse für unterschiedliche Verarbeitungsmuster Integrationspotenziale einer modernen Gesellschaft, Springer, 2(1) 75-100. http://dx.doi.org/10.1007/978-3-322-80502-7

Bilden, H. (1991). Geschlechtsspezifische Sozialisation. Neues Handbuch der Sozialisationsforschung, 4, 279-301. http://dx.doi.org/10.1007/978-3-531-19504-9_2

Brunzel, P. (2002). Kulturbezogenes Lernen und Interkulturalität: zur Entwicklung kultureller Konnotationen im Französischunterricht der Sekundarstufe I: Gunter Narr Verlag.

Daum, U., \& Sprache, G. F. D. (1998). Fingerzeige für die Gesetzes-und Amtssprache: Rechtssprache bürgernah $\left(1^{\mathrm{st}}\right.$ ed). Germany: Quelle \& Meyer.

Doleschal, U. (1998). Entwicklung und Auswirkungen der feministischen Sprachkritik in Österreich seit 1987. Germanistische Linguistik, 139, 87-116. http://dx.doi.org/10.1515/zfgl.1998.26.3.284

Endruweit, G., Trommsdorff, G., \& Berger, G. (1989). Wörterbuch der Soziologie (1 $1^{\text {st }}$ ed). Stuttgart, Germany: Enke Stuttgart. 
Fix, U. (2003). Identität durch Sprache-eine nachträgliche Konstruktion. Sprachidentität-Identität durch Sprache. Tübingen: Narr, 107-123.

Foucault, M., Raulff, U., \& Seitter, W. (1983). Sexualität und Wahrheit: Der Wille zum Wissen: Suhrkamp Frankfurt am Main.

Froitzheim, C. (1980). Sprache und Geschlecht: Bibliographie, 1,Vieweg. http://dx.doi.org/10.17877/DE290R-11799

Greule, A., Janich, N., \& Thim-Mabrey, C. (2003). Sprachidentität: Identität durch Sprache (Vol. 46503). Germany: Gunter Narr Verlag.

Grundmann, M., Hurrelmann, K., \& Walper, S. (2008). Handbuch Sozialisationsforschung: Beltz Verlag-Weinheim und Basel. http://d-nb.info/910272107/04

Hufeisen, B. (1993). "Das Weib soll schweigen..."(1. Kor. 14, 34): Beiträge zur linguistischen Frauenforschung (Vol. 19). Frankfurt: P. Lang

Illius, B., \& Gugenberger, E. (1999). Identitäts-und Sprachkonflikt in einer pluriethnischen Gesellschaft: eine soziolinguistische Studie über Quechua-Sprecher und-Sprecherinnen in Peru: JSTOR.

Lawitschka, V. (2008). Hölderlin: Sprache und Raum Tübingen, Germany.: Hölderlinturm.

Meineke, E., \& Frank, K. (1992). Sprachgewalt: Die sprachliche Reproduktion der Geschlechterhierarchie. Elemente einer feministischen Linguistik im Kontext sozialwissenschaftlicher Frauenforschung: JSTOR.

Menke, C., \& Honneth, A. (2006). Theodor W. Adorno: Negative Dialektik. http://dx.doi.org/10.1007/978-3-531-90227-2_3

Oppenrieder, W., \& Thurmair, M. (2003). Sprachidentität im Kontext von Mehrsprachigkeit. Sprachidentität-Identität durch Sprache, 39-60. ISBN 3-8233-5761-1.

Pelz, H. (1996). Linguistik: eine Einführung ( $2^{\text {nd }}$ ed): Hamburg: Hoffman und Campe.

Pusch, L. F. (1988). Sind Herren herrlich und Damen dämlich? Women in German Yearbook: Feminist Studies in German Literature \& Culture, 4(1), 19-20. http://dx.doi.org/10.1353/wgy.2012.0057

Samel, I. (1995). Einführung in die feministische Sprachwissenschaft. Berlin : Erich Schmid.

Sapir, E. (1921). An introduction to the study of speech. New York, NY: Harcourt, Brace,

Seebass, F. (2012). Friedrich Hölderlin-eine Bibliographie: BoD-Books on Demand.

Steiner, R., \& Steiner, M. (1948). Erziehungskunst: Methodisch-Didaktisches. Stuttgart: Novalis-Verl.

Trömel-Plötz, S. (2004). Gewalt durch Sprache: die Vergewaltigung von Frauen in Gesprächen (Vol. 46). Canada: Milena Corredig.

Weinrich, H. (1993). Textgrammatik der deutschen Sprache. Unter Mitarbeit von Maria Thurmair, Eva Breindl, Eva-Maria Willkop. Mannheim/Leipzig/Wien/Zürich: Dudenverlag.

This work is licensed under a Creative Commons Attribution 3.0 License. 